\title{
Octave Mirbeau, Correspondance générale
}

\section{Ida Merello}

\section{(2) OpenEdition}

\section{Journals}

\section{Edizione digitale}

URL: http://journals.openedition.org/studifrancesi/6396

DOI: 10.4000/studifrancesi.6396

ISSN: 2427-5856

\section{Editore}

Rosenberg \& Sellier

\section{Edizione cartacea}

Data di pubblicazione: 1 novembre 2010

Paginazione: 581

ISSN: 0039-2944

\section{Notizia bibliografica digitale}

Ida Merello, «Octave Mirbeau, Correspondance générale», Studi Francesi [Online], 162 (LIV | III) | 2010 online dal 30 novembre 2015, consultato il 13 janvier 2021. URL: http://journals.openedition.org/ studifrancesi/6396 ; DOI: https://doi.org/10.4000/studifrancesi.6396

Questo documento è stato generato automaticamente il 13 janvier 2021.

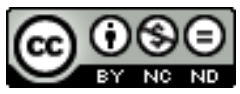

Studi Francesi è distribuita con Licenza Creative Commons Attribuzione - Non commerciale - Non opere derivate 4.0 Internazionale. 


\title{
Octave Mirbeau, Correspondance générale
}

\author{
Ida Merello
}

\section{NOTIZIA}

octAVE MIRBEAU, Correspondance générale, t. III. Édition établie, présentée et annotée par Pierre MICHEL, avec l'aide de Jean-François NIVET, Lausanne, L'Âge d'homme 2009, pp. 940.

1 Prosegue la pubblicazione della corrispondenza di Mirbeau, con questo tomo che abbraccia il periodo gennaio 1895-dicembre 1902. Nell'ampia introduzione, Pierre MICHEL traccia un ritratto del Mirbeau di quegli anni, quando era afflitto da una forma di impotenza creativa che lo aveva sprofondato nella più totale depressione. È l'affaire Dreyfus che lo costringe faticosamente a riprendere l'attività (per quanto lontana dalle sue corde sia la difesa di un militare), ed è così che pone mano al Jardin des supplices e al Journal d'une femme de chambre, dove la rielaborazione e l'accostamento di materiali disomogenei lo porta alle più significative sperimentazioni sul piano della scrittura. Michel ci porta con la consueta passione e competenza al cuore delle dinamiche di composizione di Mirbeau, che la ghiotta corrispondenza raccolta (tra i destinatari, Henri de Régnier, Claude Monet, Auguste Rodin, Goncourt, Montesquiou, Rodenbach, Mallarmé, Zola) illumina col ventaglio delle interrelazioni. 